\title{
What has Jerusalem to do with Athens? A Proposal on the Role of Theology in the Ateneo de Manila University in the Light of Karl Rahner's Evolutionary Christology
}

\author{
Edilberto C. Jimenez
}

\section{ABSTRACT}

This paper proposes a dialogue between the disciplines of theology and the natural sciences, particularly in the topic of the evolutionary understanding of the origin of humanity. The context of this dialogue is the Ateneo de Manila University, a Jesuit and Catholic university, that has among its goals the promotion of academic excellence and the formation of mature Christian faith in its students and faculty: are these two goals mutually exclusive, contradictory, or mutually enriching? The article begins with a brief history of the problematic relationship between theology and science. It then presents the transcendental christology of Karl Rahner that attempts to articulate creation and incarnation in an evolutionary perspective. The article concludes with a proposed definition of the relationship between theology and the natural sciences in the Ateneo de Manila University: theology as a "place of plurality in unity."

KEYWORDS: Jerusalem and Athens, Theology and the Ateneo

What indeed has Athens to do with Jerusalem? What concord is there between the Academy and the Church? (Tertullian 246)

Tertullian (c.160-220 CE) asked this famous question when Christianity was making frequent contact with Hellenistic thought. Although several early church fathers, like Justin Martyr, Origen, and Augustine, saw the convergence and harmony of reason (symbolized by Athens) and Christian faith 
(symbolized by Jersusalem), others like Tertulian, Basil, and even St. Paul (1 Cor. 1:21-25) saw only contradiction and paradox. Thus, Tertullian answered his own question:

We want no curious disputation after possessing Christ Jesus, no inquisition after enjoying the gospel! With our faith, we desire no further belief. For this is our palmary faith, that there is nothing which we ought to believe besides. (Tertullian 246)

In time, however, Christianity's answer to Tertullian's question was in the view of St. Clement of Alexandria's (c. 150 - c. 215). Clement approached philosophy as an aspect of the behavior of rational creatures, and therefore, is unavoidable even for Christians:

But it is said that we do not philosophize.... How, pray, dost thou love God and thy neighbor, if thou dost not philosophize? (Roberts and Donaldson 290)

Clement goes as far as to say that what is genuinely true and right about Hellenistic thought are "stepping stones" and even a peculiar "covenant" of the Greeks to Christ:

Philosophy more especially given to the Greeks, as a covenant peculiar to them-being as it is, a stepping stone to the philosophy which is according to Christ [the Gospel].... (Roberts and Donaldson 495)

The medieval era witnessed the growth of the positive relationship between ancient science ${ }^{l}$ and Christian faith. In the universities, the emergent home of the classical sciences, theology became a "science" among sciences. Scholarly churchmen like Anselm, Abelard, and Thomas Aquinas synthesized reason and Christian faith, advancing one's understanding of God through reason in order to love God more. The medieval worldview was a harmony of Christian faith and ancient Greek cosmology.

${ }^{1}$ In medieval Europe, science "was not an autonomous profession but a branch of philosophy" (Barbour 4). 
Nevertheless, Tertullian's answer to the question never disappeared; it came in the form of William of Ockham's nominalism, which did not share scholasticism's confidence in human reason's ability to establish the existence of universals, and even much less to attain certain knowledge of God that faith alone achieves.

The beginning of the modern era saw the emergence of a kind of science that was critical of the authority of ancient science, and instead based its truth on the witness of exact and empirical evidence. Some church authorities held on to literal notions of scriptural truth and authority concerning cosmological knowledge that would later be debunked by science. This resulted in the retreat of Christian theology from the knowledge of the world. John Updike draws a caricature of how theology looked like to some scientists:

Whenever theology touches science, it gets burned. In the sixteenth century astronomy, in the seventeenth microbiology, in the eighteenth geology and paleontology, in the nineteenth Darwin's biology all grotesquely extended the world-frame and sent churchmen scurrying for cover in ever smaller, more shadowy nooks, little gloomy ambiguous caves in the psyche where even now neurology is cruelly harrying them, gouging them out from the multifolded brain like wood lice from under the lumber pile. (Updike 32)

Modern science, according to Max Seckler, employs a "methodological atheism" that ignores God a priori in the construction of its theories (1073). This eventually led to the current exclusion of God from the everyday world and its practical concerns. Christian faith became a purely private matter, and was seen as a mere "opinion" synonymous with superstition and baseless myth.

This alienation of God from modern life is evident today in many Philippine universities, even Catholic ones like the Ateneo de Manila University. Aside from the increasing their religious indifference, many students and faculty ask the question about the relevance of Catholic faith in a world that understands itself in a largely secular way. An instance is the problematic place of Creation and Incarnation in an evolutionary view of the world. The Jesuit theologian Karl Rahner (1904-1984) explains the perceived irrelevance of a Christian doctrine such as the Incarnation of God's Word in such a context: 
For even if the doctrine of the Incarnation of the divine Logos is seen as a doctrine not directly denied by present-day evolutionary view of the world... it would still be experienced as something foreign to the mind of man. For a man disposed to think in terms of the evolutionary view of the world would in this case experience the doctrine of the Incarnation as something quite unrelated to his other thoughts and feelings; if such a man were or is nonetheless a Christian for some other reasons, he would then be forced to think along two completely unrelated lines of thought. ("Christology" 158)

Secular man seems unable to relate scientific descriptions of humanity and the world to divine causality and presence. Moreover, many students, teachers and researchers in the natural sciences who are sincerely committed to their Christian faith find themselves unable to reconcile their beloved faith and beloved science. Does this mean that the Christian faith is superfluous in understanding humanity and the world?

Thus, in contrast to the early Christian period, present-day Ateneo de Manila University ${ }^{2}$ asks the reverse of Tertullian's question: What has theology (Jerusalem) to do with Ateneo de Manila University (Athens)? ${ }^{3}$

\section{Karl Rahner's Evolutionary Christology}

Karl Rahner realized that a modern Christian cannot live his or her faith with intellectual honesty without facing this challenge. He acknowledged that the pervasive scholastic theology of his time presupposed a unity of knowledge and faith, and thus it could not be consistent with a modern world that denied such a unity. Rahner was one of the main movers in the Church during the Second Vatican Council (1962-1965) that sought new ways Christ is communicated to Christians in an increasingly secularized environment.

Anyone who thinks that he is able to express what is meant in the classical christology of the Incarnation in another way without doing violence to what

2"Ateneo" is Spanish for "Athenaeum," a temple of Athena in ancient Athens, where scholars and poets gathered to read their works and instruct students.

${ }^{3}$ The scope, for this paper at least, is the field of the natural sciences. The study of evolution here would be the "experimental site" in which the role of theology in the university at large would be tested. 
is meant, may express it differently. This presupposes that he respects the official teaching of the church as a critical norm for his own way of expressing it, and that he knows that this teaching has to be an indispensable norm for him.... But neither does he make its significance absolute...the official teaching of the church must also be interpreted and brought into contact with contemporary ways of thinking, and this cannot be done by merely repeating this official teaching. (Foundations 289)

Rahner, on the other hand, was convinced that theology must provide modern believers an intelligible justification of one's own personal act of believing by means of dialogue with modern secular thought:

Theology is a theology that can be genuinely preached only to the extent that it succeeds in establishing contact with the secular self-understanding which man has in a particular epoch, succeeds in engaging in conversation with it, in catching onto it, and in allowing itself to be enriched by it in its language and even more so in the very matter of theology itself. (Foundations 9)

Rahner's main contribution to this dialogue is a "transcendental Christology," which is basically a "retrieval" of St. Thomas' scholastic thought, but reexpressed in the language of Immanuel Kant and Martin Heidegger. Through transcendental Christology, he tried to interface Christian faith with various fields of scientific and secular knowledge. In particular, Rahner has written extensively on the dialogue between faith in God as creator of humans and an evolutionary view of human origins, in his article "Christology Within an Evolutionary View of the World" (which can be found in Theological Investigations, Vol. 5), which later became a key section in Foundations of Christian Faith, and in the book, Hominisation: The Evolutionary Origin of Man as a Theological Problem. Rahner established several linkages that attempted to reconcile and mutually enlighten both Christian faith and evolution.

\section{The Epistemological Link: Unity of Science and Faith}

The initial link between the two that Karl Rahner set was epistemological: how does one relate knowledge of God (faith) and scientific knowledge of the world? 
We have no direct intellectual contact with God; we, on the other hand, have direct contact and direct knowledge of the world and its objects. Some of us think of the knowledge as simply "copies" of the things around us based on our sensory experiences of them. However, Immanuel Kant demonstrated that in order for objects to be known, the sensory data that the knower collects through the senses must conform to the framework or "horizon" already set by the human mind. An object, in order to be known by the human person, must fit into this a priori or pre-arranged and ever-present framework through which the mind knows and anticipates the world. This means that it is not our knowledge that must conform to objects, but it is the objects that have to fit the prior conditions of our knowing. ${ }^{4}$

An example would be our experience of numbers. We use an implicitly known structure to recognize a certain collection of objects as containing five things. The human person is a knower who encounters and understands the world in a pre-structured or a priori way. For Kant, a priori or "pure" reason establishes the human person as a knower and is the very condition and possibility for knowing the world and its objects. Pure or a priori reason is pre-conceptual, i.e., not articulated or conceptualized into an explicit idea, although we can attempt to describe and explain it as we are doing now!

Kant further describes the human person as a knower who is "troubled by questions that it cannot dismiss, because they are posed to it by the nature of reason itself, but that it also cannot answer, because they surpass human reason's every ability" (Kant 5). We humans are finite beings who in every act of knowing unceasingly ask the question, "What can I know?"

Following Kant, Karl Rahner described the human person as a knower who possesses an a priori structure of knowing, willing, and questioning. Rahner used a word Kant also used, "transcendence," and redefined it to denote our a priori tendency to go beyond ourselves and even the objects of the world to "absolutely everything," not only to particular beings, but to "being" as such.

4"Thus far it has been assumed that all our cognition must conform to objects... Hence all objects of experience must necessarily conform to these concepts and agree with them." (Kant 21-22)

${ }^{5}$ For Kant, a priori reason is "transcendental": "I call transcendental all cognition that deals with not so much with objects as rather our way of cognizing objects in general insofar as that way of cognizing is to be possible a priori" (Kant 64). 
Transcendence is not the experience of some definite, particular thing which is experienced alongside other objects. It is rather a basic mode of being which is prior to and permeates every objective experience. Transcendence is the a priori openness of the subject to being as such, which is present precisely when a person experiences himself as involved in the multiplicity of cares and concerns and fears and hopes of his everyday world. (Foundations 34-35)

Because of these experiences of transcendence, every object that comes our way is relativized. We are convinced that there is more to every finite thing, and we are never satisfied with them. For us, every answer is just the beginning of a new question. This means, still possess ourselves in freedom and responsibility, and are not possessed by these objects: we transcend the objects of the world.

The boundaries of our knowledge and intentionality of the world point asymptotically to an infinite horizon. Human persons are more than the products of the finite world and are more than what the specific empirical sciences say. For we are ultimately not objects, but embodied spirits, who through our awareness of our finitude are open to and are drawn towards an ever-broadening "horizon," that infinite, unreachable and unknowable, mysterious (Foundations 32). Every concrete experience of transcendence shows that the human person is neither at the disposal of things, nor self-sufficient, but rather is at the disposal of the horizon called Holy Mystery, who is not a finite individual alongside other objects but is the boundless horizon that grounds all objects and our own selves in our knowing and willing (Foundations 77).

Mystery is rather something which exists and confronts us as the unfathomable...the horizon which cannot be mastered and which masters all our understanding, and which allows the other to be understood by being present itself in its silence and its incomprehensibility.... It is rather the characteristic which always and necessarily characterizes God, and through him characterizes us. (Foundations 217)

Christians denote Mystery with the word "God," not as "answer" which solves it, but as a question that points to infinite silence and darkness (Foundations 48). The word does not mean that we control God; on the contrary, as question the word acknowledges our absolute dependence on Mystery, a relationship 
Rahner called creation. This dynamism of transcendence towards Holy Mystery, towards God, is what defines the human person in its very essence:

\begin{abstract}
Man is understood as the existent of transcendental necessity who in every categorical act of knowledge and of freedom transcends himself and the categorical object towards the incomprehensible mystery by which the act and the object are opened and borne, the mystery which we call God.
\end{abstract} (Foundations 209)

Karl Rahner's philosophical anthropology thus describes the human person as essentially a creature who in the experience of transcendence is both radically different from and radically dependent on and orientated to God as Holy Mystery. God is, therefore, not just one object among other objects of our knowledge, but is the very condition of the possibility of the knowledge of the world and its objects. We are not just "spirits," but rather "spirits in the world." Though this does not prove God's existence, it shows to people who already believe in God that our listening to the sound of the world is conditioned by the prior possibility of our capacity to be "a hearer of God's Word."

For Rahner, then, our scientific knowledge of the world is a small island in the vast sea of unknowable Mystery:

In the ultimate depths of his being man knows nothing more surely than that his knowledge is only a small island in a vast sea that has not been traveled. It is a floating island, and it might be more familiar to us than the sea, but ultimately it is borne by the sea and only because of this we are borne by it. (Foundations 22)

Rahner acknowledges the success of modern science and affirms its value and validity. What he questions is "its exclusive claim" to be the most fundamental kind of knowledge. Rahner cites church teachings that warn against a tendency of some evolutionary scientists to reduce all knowledge to scientific knowledge:

The Church has given express warning against an evolutionary theory that transposes knowledge regarding one definite domain in a uniform way to all domains, and on a monistic or pantheistic basis seeks a facile explanation of 
the reality and origin of everything in the concept of "development" or "evolution," and which finally ends up as a "dialectical materialism", or casts doubt on the essential difference between spirit and matter. (Hominisation 18)

For transcendental experience, faith operates not only as a qualitatively different kind of knowing but as the fundamental act of knowing permeating all experience and even scientific knowing (Dych 19).

Faith, then, is not a second-class kind of knowledge that gets involved only when gaps appear in our scientific knowing. One can conclude that the knowledge of faith is not secondary but is in fact prior to scientific knowledge. Consequently, theology studies this transcendental experience of God as Mystery, which lies at the beginning, and not at the end, of the act of knowing, and it does not only "amplify" secular knowledge but is its "slender root" and "deeper source."

We may say that today theology and faith must reflect upon their place of origin, which lies deeper and more fundamentally in human existence, prior to the plurality of ways of understanding the world and existence. Thus, theology can and must be seen as the study of faith at a level prior to that of the secular sciences, speaking to man before he "goes out" into the unintegrable pluralism which is his existence and his world ... This may provide the impetus to a new and more original self-interpretation of theology. ("Philosophy and Philosophizing" 56)

\section{The Metaphysical Link: Unity of Matter and Spirit}

Aside from the epistemological link, William Dych traces three other linkages between faith in Jesus Christ and an evolutionary view of the world (Dych 69-70):

- The unity between matter and spirit in the sense of the evolutionary movement of the material world towards spiritual existence (metaphysical).

- The unity between nature and grace (historical). 
- The intrinsic unity between the union of human beings with God in grace and the hypostatic union of the man Jesus with God (anthropological and theological).

Natural science, on the other hand, understands the human being as a corporeal entity. Science, as an important element of humanity's one and complete knowledge, "knows a lot 'about' matter, i.e., it defines ever more exact relationships of a 'functional' kind between the various phenomena of nature" ("Christology" 162).

Unfortunately, some scientists have attempted to reduce all human realities to purely bodily operations: they consider the human mind as electrochemical reactions in the brain or all human traits as contained in the genetic code, etc. This amounts to reducing spirit to a mode of matter. Rahner sees this reductionism as distorting not only our knowledge of the integral human person, but even our knowledge of matter itself:

Since, however, natural science does its work in methodical abstraction from man himself, while knowing a great deal about matter it cannot know matter itself, even though this knowledge about the functional and temporal relationships of its isolated object does in the end lead it back again to man himself in an a posteriori manner. ("Christology" 162)

Only from the perspective of the whole human person is it possible to say what matter is, and not vice versa, because the whole cannot be determined by the same means as those used for the determination of the parts ("Christology" 162).

For Rahner, Christians should insist that the human person is one substance possessing unity of spirit and matter:

Man is one substance, but in such a way that his unity is ontologically prior to, and comprises, a real and genuine, irreducible plurality and essential composition. Man is one by origin, nature and last end. (Hominisation 18)

This unity prior to the plurality of components implies that "every statement about one part of man implies another statement about the whole man," and 
that "all problems are far from being solved when the evolution of man's 'body' is admitted, and excluded from his 'soul' (Hominisation 18). A statement about the human body implies a related statement about the human soul, and vice versa. This does not mean, however, that one component is reducible to the other: that the spirit is a mode of matter, or that matter is merely the external manifestation of the spirit that we are. Though distinct, matter and spirit are inseparably united.

Starting from this original unity of matter and spirit in the human person, Rahner defines "spirit" in man as self-transcendence towards Mystery:

Spirit is the single person insofar as he becomes conscious of himself in an absolute presence to himself, and indeed does this by the fact that he is always oriented towards the absoluteness of reality as such, towards its one ground whom we call God. ... Insofar as the single person experiences himself in this way, he can and has to say: I am spirit. (Foundations 183)

But man is not a "pure" spirit, but a "spirit in the world" of space and time, in the midst of other things and embodied spirits, in which matter becomes the condition for both the experience of the spirit's estrangement from itself and direct communication with other spiritual existents in space and time; ergo, in history:

A person experiences both himself and the world which directly encounters him as matter insofar as he experiences his own facticity, experiences himself who is a given and is to be accepted and is not yet comprehended; in so far as...there stands something which is not himself.... Matter is the condition which makes possible the objective other which the world and man are to themselves.... Matter means the condition for that otherness which estranges man from himself and precisely in doing so brings him to himself. (Foundations 183)

Therefore, whereas science deals with the human person as a corporeal being and as matter, theology points to the whole person as a unity of spirit and matter. 


\section{The Historical Link: Unity of Nature ${ }^{6}$ and Grace}

Evolution is distinct from other theories in biology in the sense that it does not predict future phenomena, but is backward-looking and seeks to explain the historical origins of present species from simpler and more primitive species through the interplay of natural selection and genetic mutation. Some scientists employ the phenomena of natural selection and mutation to paint evolution as a process of the triumph of the strong at the expense of the weak and of how blind and capricious chance "determines" the traits that will appear. Evolution seems to be a grand lottery-cum-reality show (very much like Survivor) whereby by luck and savagery humans end up holding the winning ticket. Consequently, there is no God and no direct creation of the world that the Bible creation narratives proclaim.

For Karl Rahner, however, if one looks at the same world through the eyes of faith, one discovers a different story. Looking towards the beginning of life, Rahner sees the history of matter as "developing out of its inner being in the direction of spirit" " Christology" 164). Evolution is not conceived as the product of the survival of the fittest and chance, but as a "becoming," or "becoming more," surpassing oneself and becoming something essentially "higher" (Foundations 184-85). The data and facts provided by evolutionary science can be seen as conforming to or fitting this optimistic interpretation of history. The facts of evolution can show that, indeed, there is an intimate link between the history of the world and the emergence of humanity: the evolution of life reaches its apogee in the human person:

the history of nature develops towards man, continues in him as his history, is preserved and surpassed in him, and therefore reaches its goal with and in the history of man's spirit. (Foundations 187)

For Rahner, the evolution of nature culminates in the human person because it is in the emergence of humanity that all nature achieves self-consciousness in freedom towards spirit.

Rahner describes nature's evolutionary history as an ascent of matter towards spirit, which finds its climax in humanity, an embodied spirit that

"Nature" here is understood in the scientific sense and not in the scholastic sense, although the latter sense is normally associated with grace. 
possesses self-conscious dynamism and transcendence towards God. For Rahner, Christians also perceive/understand/believe in that same evolutionary history God's descent towards self-communication and revelation.

This self-transcendence of the cosmos in man towards its own totality and towards its own ground does not reach its ultimate fulfillment until the cosmos...receives the immediate self-communication of its own ground in the spiritual creatures which are its goal and its high point.... Not only does God create something different from himself, but he also gives himself to this other. The world receives God...in such a way that he himself becomes its innermost life.(Foundations 190-91)

God's self-communication in the world is Rahner's definition of the word "grace." Grace is God's actual presence and indwelling in history (Dych 39). And this definition implies that what Christians call "grace" is not extrinsic to the history of nature but is coextensive with it and is in fact history's deepest identity. History is understood both as the story of God lovingly and freely communicating Godself to humankind, and the story of humanity responding to this loving offer in terms of "obedient acceptance of his transcendental orientation to the God of eternal life" (Foundations 152). Rahner established the unity and relationship between the evolutionary history of nature and the gracious event of God's self-communication to nature, or more simply, the unity of nature and grace: "Man is the event of the free, unmerited and forgiving, and absolute self-communication of God" (Foundations 116).

\section{The Christological Link: The Hypostatic Union}

Nature, as an ascending anthropology, and grace, as a descending theology, form a concrete and evolving history, a single history of the world and of humankind. Karl Rahner describes this single history as an evolution of these two dynamisms:

... the history of the transcendental revelation of God will necessarily show itself again and again to be a history which is taking place in an irreversible direction towards a highest and comprehensive self-interpretation of man. Consequently, it will be ever more intensely an explicitly religious self- 
interpretation of this supernatural, transcendental, and revelatory experience of God. (Foundations 154)

Rahner traces the trajectories of these two dynamisms as they evolve in history. The divine self-communication of God as Spirit wills loving union with humanity. Through this very same grace, the human person desires immediacy with God. Since we actualize ourselves within history, these two dynamisms must find their climactic realizations in history. Rahner calls the human transcendental orientation the search for an absolute savior:

Man is searching for the absolute savior, and he affirms at least unthematically his past or future coming in every total act of his existence which is finalized by grace towards immediacy with God. (Foundations 298)

Absolute savior does not merely teach or promise salvation, but is salvation, precisely as God's absolute and historical offer of self to humankind. At the same time, the absolute savior is the climactic moment of the human dynamism of responding to the loving self-communication in faith. The absolute savior is a human person who is united to God in a radical, unsurpassable, and irrevocable way. And the life of obedience and trust of the savior to God will reveal human fulfillment in union with God.

Therefore this savior...must be at the same time both the absolute promise of God to spiritual creatures as a whole and the acceptance of this selfcommunication by the savior. (Foundations 195)

For Christians, the absolute savior is none other than Jesus Christ, the God-Man:

... in Jesus Christ, the God who communicates himself and the man who accepts God's self-communication become irrevocably one, and the history of revelation and salvation of the whole human race reaches its goal.(Foundations 169)

God, in willing to be lovingly united to humanity, communicates Godself in history through Jesus Christ. Jesus, truly divine, in his true humanity becomes the absolute and unsurpassable expression of God's kenosis or self-giving 
even up to the point of death. The hypostatic union of Jesus' true humanity and true divinity now defines the human person as the very self-expression and concrete embodiment of God. "Christ is therefore human in the most radical way" because in him humanity becomes the self-expression of God (Foundations 226). In the union of humanity and divinity in Jesus, being God and being human are no longer seen as contrary opposites but have become united and distinctly realized.

The Jesus-event, the Incarnation of God, is therefore not an anomaly in history, but is the very culmination of evolution and history, the biblical "fullness of time" (Gal. 4.4): The Incarnation is not an abrupt interruption or aberration in the "normal" course of history, but the "fullness of time," the culmination of a movement which began with creation itself. (Dych 79)

\section{Plurality in Unity}

More recently, Ian Barbour outlined four kinds of relationships between religion and modern science (77-105): ${ }^{7}$

1. Conflict. The Galileo and Darwin cases are famous examples of this image of the "warfare between science and religion;" that this relationship betrays a misunderstanding of science.

2. Independence. Science and religion are totally independent and autonomous from each other. This approach relegates God only in the religious sphere and excludes Him from our everyday life. For Rahner, such an attitude would be a denial of our Christian faith in God as our Creator and in Christ as Redeemer of our corporeal humanity.

3. Dialogue. Although science and religion would insist on their own methods and presuppositions, they were aware of the fact that the total picture of reality

"Ian Barbour emphasizes the fact that each approach has different versions, each version having its own methodology and starting point, which echoes Rahner's idea of the "unity in plurality" represents only one variation of the dialogue approach. 
would not be complete without the other. This approach is most fruitful for both science and religion.

4. Integration. Proponents of this approach aim to unify science and religion into a single discourse.

Rahner's attempt at forging a mutually enriching relationship between science and Christian faith certainly falls under the dialogical approach described above. Through this cursory dialogue between Christian faith and evolution, Rahner was able to establish a basic principle of the dialogical relationship between theology and the natural sciences: plurality in unity:

This substantial unity of man, which is not a conjunction of already existing things, but holds variety in unity as the realization and accomplishment of one essence, is not a defined truth of faith, but is a fundamental presupposition of the Christian understanding of man, his world, and the history of his redemption. Only in that way, for example, can it be true that, as Tertullian put it, caro cardo salutis (the flesh is the hinge of salvation); that the Word became flesh; that there is no abyss between the secular world and the sacred economy of redemption; that there is a resurrection of the flesh; that we are redeemed by a death, that is, by what is also a biological event; that by signs and wonders the other world can announce itself in this tangible world; that the Church is a visible society with significance for salvation, and so on. It is, therefore, understandable that ecclesiastical theology was not swift and eager to accept a proffered harmonization of science and belief which delivered the body to science in order to save at least the soul for theology...such a delineation of respective domains can only be a pointer indicating that on account of the plurality in unity, both partners and authorities must really have their full say regarding the whole reality of man in his unity, though each will make its pronouncements with a different part of human reality as its basis. (T.I. 5, 19)

Basing himself on the unifying Christ-event, Rahner shows in several ways the indispensable role of theology: he points out the need to understand the world and humanity not simply in its material aspect, but as a pluralityin-unity: knowledge of faith and knowledge of science; matter and spirit; grace and nature; God and humanity. Likewise, Rahner shows that plural- 
ism implies the autonomous but indispensable place of the various sciences in completing a holistic understanding of the world and humanity. Rahner's dialogical approach implies that Christian faith must listen assiduously to the sciences and reformulate its convictions and doctrines that relate to the issues and questions that the sciences have raised about the world and humanity.

It follows that there is a genuine plurality of propositions about man, and despite the ultimate unity of a systematic doctrine of man...there are in principle several sciences which can and must treat of man. These are irreducible to one another as their different subject matters, which themselves necessarily follow from the complex nature of man, and yet they form a unity just as man does.(T.I. 5, 21)

Without this "plurality-in-unity" espoused by theology, universities, especially those who ignore or resent the religious dimension of life, will fall into the trap of absolutizing immanent material reality:

For this reason theology stands as the official representative of a radical opposition to any attempt to absolutize any reality which can be experienced immanently and any immanent value, and the servants of these realities are also the natural sciences. ("Today" 63)

Natural scientists too should constantly accept theology's reminder that the world view which is actually a part of their lives and not just something conceived by the monopolistic claims of the natural sciences is something which cannot be determined by their natural science alone; that spirit, freedom, fidelity, love, the infinite question of existence cannot be "explained" by natural science alone, even though the attempt is made over and over again. ("Today" 65-66)

\section{Conclusion}

Finally, we arrive at the answer to the question "What has Jerusalem to do with Athens?" What has theology to do with the Ateneo de Manila University? 
Scientific progress, despite its benefits, has brought about the unfortunate divorce between Christian faith and daily life. This rift was aggravated by those Christians who were not able to relate their faith to a world that understood itself apart from faith. This fragmentation is also mirrored in many universities, which have fragmented into many disparate fields of inquiry despite its ancient ideal of unity of the various fields of knowledge, going against the very notion of "uni-versity." This pluralism has taken its toll not only on theology but basically on the rest of the Humanities: the divorce of the natural sciences from the Humanities has set it adrift and fragmented, for knowledge of the human spirit has lost its center.

Karl Rahner's evolutionary Christology forms a locus of dialogue between theology and the natural sciences, showing that beyond the plurality of knowledge there is a prior and fundamental unity:

Theology's all-embracing character makes it a suitable space for dialogue between the disciplines to occur. Since the Christian God is the Creator and Lord of all reality, systematic theology must integrate the wealth of insights from all secular disciplines. In performing this task, interdisciplinary dialogue will take place and creative transformation of both sides may occur, and new possibilities may open up. ${ }^{8}$ (Kwan 81 )

Therefore, Ateneo de Manila University needs theology to be a "place of plurality in unity" where interdisciplinary dialogue can occur, where the plurality of knowledge can come together to form an integral picture of the world and of humanity as forever united with God through its absolute Savior, the God-Man, Jesus Christ.

This theological criticism will not become part of the principles and methodologies of the individual science as such, but rather it will surround them like a distant horizon; it will address itself to the scientist and not to the individual sciences in its abstract form. ("Today" 64)

${ }^{8}$ Kai-man Kwan believes that just as the university needs theology, so does theology need the university to constantly renew and re-express itself to the ever-changing environments, whether in the sciences or in the humanities. 
Gregory Peterson calls theology within a university the "department of ultimate concern." Scientists like those trying to understand the origin of the whole universe sometimes go beyond their particular field and ask questions about meaning, purpose, and destiny. Theology is one such "place" (aside from philosophy) where such questions can be discussed in dialogue with the different disciplines.

Concerned as it is with the whole of reality, a department of theology may serve as an important place where disciplinary barriers break down. Because theology is precisely concerned with the meaning of the whole, the study of theology involves the kind of cultural and (ideally) scientific literacy that typically is not available elsewhere. ("Today" 64)

This role of theology in the Ateneo de Manila University will hopefully strengthen the identity and character of the Ateneo as a Jesuit and Catholic University that "seeks to serve the Faith and to interpret its teachings to modern Philippine society." (Ateneo 8)

\section{Works Cited}

Ateneo de Manila University Loyola Schools Student Handbook. $35^{\text {th }}$ ed. Quezon City: Office of the Associate Dean for Student Affairs, 2002.

Barbour, Ian G. Religion and Science: Historical and Contemporary Issues. San Francisco: HarperCollins, 1997.

Dych, William. Karl Rahner. London: Continuum, 1992.

Fisichella, Rino and Max Seckler. "Theology.” Dictionary of Fundamental Theology. Ed. René Latourelle and Rino Fisichella. Middlegreen Slough, UK: St. Paul's, 1994, 1060-80.

Kant, Immanuel. Critique of Pure Reason. Trans. Werner S. Pluhar. Indianapolis: Hackett Publishing, 1996.

Kwan, Kai-man. "Christian Theology as an Academic Subject in a University." Quest 1:1 (2002). Rahner, Karl. "Christology Within an Evolutionary View of the World." Theological Investigations. Vol. 5. Baltimore: Helicon Press, 1966.

- - Foundations of Christian Faith: An Introduction to the Idea of Christianity. Trans. William V. Dych. New York: Crossroad, 1978.

-_- Hominisation: The Evolutionary Origin of Man as a Theological Problem. Trans. W.J. O'Hara. New York: Herder \& Herder, 1965. 
What has Jerusalem to do with Athens?

"Philosophy and Philosophizing in Theology." Theological Investigations. Vol. 9. Baltimore: Helicon Press, 1961.

-_- "Theology Today." Theological Investigations. Vol. 21. New York: Crossroad, 1988.

Roberts, Alexander and James Donaldson, eds. Ante-Nicene Fathers: The Writings of the Fathers Down to A.D. 325. Vol. 2: Fathers of the Second Century: Hermas, Tatian, Athenagoras, Theophilus, and Clement of Alexandria. Peabody, MA: Hendrickson Publishers, 1994.

Southgate, Christopher, et al, eds. God, Humanity and the Cosmos: A Textbook in Science and Religion. Harrisburg, PA: Trinity Press, 1999.

Tertullian. "The Prescription Against Heretics." Ante-Nicene Fathers: The Writings of the Fathers Down to A.D. 325. Vol. 3: Latin Christianity: Its Founder, Tertullian. Ed. Alexander Roberts and James Donaldson. Peabody, MA: Hendrickson Publishers, 1994.

Updike, John. Roger's Version. New York: Ballantine, 1986. 